\title{
Accounting Teachers' Readiness to Use Mobile Phones and Social Media Platforms as Supplementary Teaching and Learning Tools in the $21^{\text {st }}$ Century
}

\author{
Melikhaya Skhephe ${ }^{1}$, Christabel Dudu Mantlana ${ }^{2 *}$ and Berington Zanoxolo Gobingca ${ }^{3}$ \\ ${ }^{1}$ University of Fort Hare (South Africa) \\ ${ }^{2}$ Walter Sisulu University (South Africa) \\ ${ }^{3}$ Walter Sisulu University (South Africa) \\ *Corresponding author \\ Dr M Skhephe, University of Fort Hare, South Africa
}

\begin{abstract}
This research study sought to examine Accounting teachers' readiness to use mobile phones and social media platforms in their teaching practice. To this end, the researchers employed a qualitative approach and a case study. Data were obtained through interviews, with the sample of four participants having been purposively and conveniently selected. The findings revealed that the participating Accounting teachers were unaware that they could make use of mobile phones and social media in their classrooms. Another finding was that the constitutions of the participating schools prohibit the use of such devices in class and on the terrain. The researchers recommend that discussion forums be created to support the use of mobile phones and social media in the classroom. Accounting teachers needs to remember that learners are already au fait with most devices, and these technological tools offer teachers a wonderful opportunity to enhance their teaching, while allowing learners to access a variety of platforms to enrich their learning. Another recommendation is that mobile phone and social media usage be allowed and the recording of lessons be encouraged. Urging teachers to create blogs will further inculcate the use of mobile phones and diverse social media as part of their teaching pedagogy.
\end{abstract}

Key words: $21^{\text {st }}$ century, Accounting teachers, mobile phones, readiness, social media 


\section{$2^{\text {nd }}$ World Conference On Future Of EDUCATION}

BRUSSELS, BELGIUM

11-13 September 2020

\section{Introduction and background}

Mobile phones and social media platforms are very important in the lives of youths, in both the developing and the developed world (Moura \& Carvalho, 2008). In the $21^{\text {st }}$ century, the use of mobile phones and social media is an everyday reality in learners' lives, and that statement will increasingly be true in the future. For that reason, sooner or later these technologies are set to become generally accepted as learning tools, as has been the case with videos, computers and the internet (Naismith et al., 2004). Owuse-Acheaw and Larson (2015) confirm that the use of social media has become common among people of different age groups, to the extent that what used to be a hobby for some, has now become a way of life for many. Olaleke, Iroju and Olajide (2015) concede that young people have embraced mobile phone usage, along with social media as platforms for communicating, downloading and sharing information, having done so from an early age.

For that reason, teachers would be wise to make use of these platforms as a means of supplementing their teaching and learners' learning - especially if they wish to grab their changes' attention while delivering quality education in the process (Olaleke et al., 2015). Kismihok (2007) admits that the notion of using mobile phones in the classroom as an educational tool has been met with prejudice and resistance around the world. Cetinkaya (2017) states while not all mobile phones are primarily used to access social media platforms, they have become part of users' daily lives, and can indeed be used for educational purposes. As Van Doorn and Eklund (2013) opine, mobile phones and social media platforms are changing the ways in which knowledge is digested and taught in classrooms, by providing teachers and learners with new avenues for effecting communication, delivering the curriculum and facilitating learning. Lewis (2006) found that, in the United Kingdom, mobile phones and social media platform use in classrooms have become so ubiquitous, that they have reduced both the lesson set-up time and the need to offer training on the use of such devices. Green and Hannon (2007) state that in most African countries, teachers lack the confidence to use mobile phones and social media as supplementary tools when teaching, and concede that no policies are in place to allow learners to use their own devices on the school terrain. In South Africa, educational inequality remains one of the indelible legacies of apartheid-era segregationist policies. For poorly resourced communities, and in rural settings where education systems cannot meet societal demands, rapidly evolving mobile technology is providing new opportunities for learning. For that reason, many communities in this country have embraced or seek to embrace these devices for their ability to expand the educational curricula, increase teacher and learner efficiency, and improve the quality of teaching (Ed Technology Tours, 2017).

\section{Statement of problem}

In the $21^{\text {st }}$ century, which is characterised by the dominance of technology across of all spheres of society and all sectors, one of the main questions currently facing Accounting teachers is what might prompt them to adopt the use of the available tools (mobile phones and social media platforms) in their own classrooms, to supplement their teaching and enhance learning. Another question which arises is the following: Do teachers' inherent qualities, their personalities and backgrounds, play a role, or is teachers' acceptance (or rejection) of technology driven by other, external factors? As Naismith et al. (2004) point out, the use of mobile phones and social media 


\section{$2^{\text {nd }}$ World Conference On Future Of EDUCATION}

BRUSSELS, BELGIUM

11-13 September 2020

is an everyday reality in the lives of the vast majority of learners, and Moura and Carvalho (2008) concur with that view. That begs the question: What causes Accounting teachers not to use mobile phones and social media platforms as supplementary teaching and learning tools: is it a lack of related resources in schools, or teachers' lack of appropriate knowledge, skills and expertise? Given this conundrum, the authors sought to explore Accounting teachers' readiness to use these technologies as supplementary teaching and learning tools, by undertaking a case study as part of their research in the Eastern Cape province of South Africa.

\section{Main research questions}

The main research question being addressed in this study, is: Why do Accounting teachers not use mobile phones and social media platforms as supplementary teaching and learning tools in their classrooms?

The sub-research questions derived from the main question are:

- How are mobile phones and social media platforms used to supplement the teaching of Accounting?

- What challenges do Accounting teachers encounter in utilising mobile phones and social media platforms in their classrooms?

\section{Objectives of the research}

The identified objectives included determining how Accounting teachers make use of mobile phones and social media platforms to enhance the teaching of Accounting, and examining the challenges which these teachers encounter in using mobile phones and social media platforms in their classrooms.

\section{Significance of the research}

This research aims to offer all educational stakeholders an opportunity to understand how mobile phones and social media platforms can be used to support the teaching practices of Accounting teachers and the learning of their charges, who now spend more time on their mobile phones and on social media, than they do reading books.

\section{Theoretical framework}

Based on global expectations and changing realities related to the way in which technology is influencing the teaching of all subjects (for our purposes, Accounting) in this highly technologised era, Davis, Bagozzi and Warshaw (1989) propose the Technology Acceptance Theory (TAT) as being ideal for underpinning research related to this field. For that reason, their theory was deemed appropriate for framing the investigation reported on here. TAT is used to predict or determine why some people adopt and use technology, while others do not. The theory further states that all users are able to develop new skills and knowledge of current technologies, by continuously improving their capacity and upgrading their skills. However, implementing the necessary changes presents a variety of challenges (Davis et al., 1989). Certain factors, such as the cost of technology adoption, along with individual differences amongst users, are too significant and may represent enormous barriers that need to be overcome. Decision-makers need to keep these obstacles in mind, if they are to succeed at diffusing and deploying technology in schools. Straub, Lock and Hill (2001) observe that, in 


\section{$2^{\text {nd }}$ World Conference On Future Of EDUCATION}

11-13 September 2020

the context of TAT, educational background, beliefs and personal biases are all factors that determine or affect users' acceptance of newly introduced technologies, and/or the transfer of technology. Indeed, the amount of information circulating through modern information systems is so vast that it is impossible to manipulate or navigate without the aid of technology. As Davis et al. (1989) point out, however, any high-performance information system will have little value unless users adopt, or for any reason reject, that technology. TAT compels current and potential systems developers to understand the reasons why users accept or reject certain systems, with a view to modifying future offerings. Venkatesh et al. (2003) believe technological innovations need not only to be accepted, but must actually be used. TAT proved helpful for a study of this nature, since the modes of delivering information in the classroom are constantly changing - that means their validity and accuracy may change over time, depending on the discovery of new contributions to the field. TAT (Davis et al., 1989) is highly relevant to this research, since it is an information systems theory that examines how users come to embrace and implement technology in a meaningful way. Successful adoption will mean that everyone employs the technology for its intended purpose (Davis et al., 1989). TAT further suggests that when users are presented with a new technology, a number of factors influence their decision about how and when they will use it (Davis et al., 1989). In the view of the developers of this theory, the capacity to know is more critical than what is actually known (Davis et al., 1989).

\section{Literature review}

In this research study, the extant literature on the use of mobile phones and other devices as supplementary teaching tools in $21^{\text {st }}$-century classrooms, was reviewed under the headings given below.

\section{Short Message Service (SMS)}

Research has shown that one feature of mobile technologies`, namely Short Message Service (SMS) texting on cellular phones, ${ }^{1}$ has great potential in the classroom (So, 2009). Hayati, Jalilifar and Mashhadi (2013) confirm that using educational SMSes in the classroom involves teachers relying on such tools to deliver educational content, in addition to SMSes enhancing learners' command of English (more so than an in-class contextualised learning and paperbased self-research approach would allow). Hayati et al. (2013) concur that the teaching of Accounting requires a sound grasp of English, when accessing the wealth of information available on the web. Cavus and Ibrahim (2009) argue that the potential in using educational SMSes to enhance learning, lies in the interrelated technological and pedagogical aspects inherent to this method. In addition, SMSes allow learners to learn at their own pace, even away from the traditional classroom (Cavus \& Ibrahim, 2009). Basoglu and Akdemir (2010) opine that SMS use in teaching offers the benefit of being able to learn on the move, regardless of the learner's location, thus offering a platform that is both flexible and personalises the learning environment. Harley et al. (2007) concur that the convenience of offering learners small "chunks" of educational content on easy-to-access and easy-to-use mobile devices, rather than using paper-based educational materials in class, has helped to enhance their learning. 


\section{$2^{\text {nd }}$ World Conference On Future Of EDUCATION}

BRUSSELS, BELGIUM

11-13 September 2020

\section{Facebook}

Salameh (2017), who investigated the attitudes of Saudi learners towards the knowledge and skills they found in Facebook web pages, reported that that platform has the potential to supplement learners' education with secondary sources that can enhance their knowledge and skills, and improve their academic achievement. Salameh (2017) further found that the use of Facebook as a teaching and learning tool in the classroom holds marked benefits, since learners start to navigate this platform at an early age, and spent most of their time reading posts or posting on their own pages. Hassan and Dickson (2014) reveal that millions of learners access Facebook on a daily basis, to connect with family and friends, search for information or play games. Furthermore, many learners spend a great deal of time socialising with their friends on Facebook, which means they have less time to do researching by consulting books or academic websites. To maximise the benefits which can be obtained from Facebook, rather than opposing the use of this platform, teachers can creatively employ this as a tool for supporting learners' continuous learning activities. Facebook offers teachers an opportunity to interact with learners inside and outside the classroom: they can send assignments, share information with the class, and ask and answer subject-related questions about how to create digital model utilizing AutoCAD. For digital modelling class leaners received instruction for tutorials and quizzes can be sent via the Curriculum Information Document Online System (CiDOS), which stores notes, quizzes and tutorials for all subjects offered in schools. To awaken the interest of learners, communication must be seamless and effective when using Facebook, and it must serve the dual purpose of allowing learners to communicate with their classmates and their teachers.

\section{WhatsApp}

WhatsApp is a free messenger application (app) that works across multiple platforms such as iPhone and android phones; it is widely used among learners, teachers and family members to send multimedia messages including photographs, videos and audio, along with simple text messages (Gon \& Rawekar, 2017). Gon and Rawekar (2017) add that since an internet facility is required for using WhatsApp, large segments of information can be accessed in real time, and sharing that information occurs instantaneously and conveniently. According to Bere (2012), WhatsApp messenger has the following important features that can be used for teaching and learning:

- Offline messaging: messages are saved automatically when the device is off or outside an area where there is coverage.

- No charges involved: there are no additional charges involved for using WhatsApp, as it uses the same internet data plan which allows email messaging and web browsing.

- Pin and user name: WhatsApp users need not remember passwords or usernames, as the service works via phone numbers and integrates with users' address books.

Amry (2014), who investigated the effectiveness of WhatsApp social networking, when compared to face-to-face learning in a classroom, explains that WhatsApp has significant potential to support the learning process and has major implications for pedagogies, in that it grants the user direct access to a wealth of online resources, and shifts the focus to learners' creativity, autonomy and responsibility in respect of their own learning. Marshall (2014) supports the use of WhatsApp in the classroom, arguing that learners remember only ten per cent of what they read, 20 per cent of what they hear, 30 per cent of what they see, but 50 per cent of what they hear and see. 


\title{
$2^{\text {nd }}$ World Conference On Future Of EDUCATION
}

BRUSSELS, BELGIUM

11-13 September 2020

\begin{abstract}
Podcasts
The word "podcast" comes from a combination of the words "iPod" and "broadcast" (Campbell, 2007). As Campbell (2017) elucidates, podcasting refers to the use of any portable audio player that allows the user to download sound files from the internet. Prensky (2011) states that the current generation of learners has grown up and lived with digital technology. Thus, since young people are familiar with downloading audio files from the internet and own their own audio players, the adoption of this method of learning would be almost automatic. Prensky (2011) further observes that podcasts allow teaching and learning to continue anywhere, at any time. Podcasts permit learners to access educational materials at home, while working on other schoolwork or doing activities of their choosing. That means they can play the recordings at a time which is convenient to them, rather than being confined to set periods or class schedules. Podcasts have an obvious place in distance education, fulfilling the same role that audiocassettes performed not too long ago. However, through web delivery access is much easier, and is often effected via e-learning systems which are already in place at most schools (Townend, 2015). Podcasts are fairly easy for teachers to generate using audio recorders and commonly available free compression software (Campbell, 2007). For the majority of academics who are not used to producing sound recordings, podcasts will need preparation to ensure a "compelling listening experience" (Campbell, 2007). As Sharples, Taylor and Vavoula (2005) elaborate, when used in an educational setting, podcasts allow the teacher to choose appropriate content, set learning objectives or goals, design the content, produce the podcast, and integrate it into the subject.
\end{abstract}

\section{Tablets}

Kismihok (2007) confirm that technology is invading the domain of education at an increasingly rapid pace. The process has effectively evolved from learning on blackboards to learning on interactive whiteboards. Tablets can supplement teaching in the classroom, by bringing in a number of features:

Direct communication: tablets can connect all major educational stakeholders, including learners, parents and teachers. Handwritten notes or tasks tend to get lost, but this is not the case with digital data - any feedback (including criticism, kudos or concerns) form part of a permanent record, further reference.

Faster visualisation, quicker reporting: tablet use may be incentivised by demonstrating how portable they are. For instance, when teaching learners certain scientific skills, they may use these devices to document field trips to a heritage site or museum. Aside from allowing the user to take pictures, tablets and smartphones can show interactive maps of facility-specific content.

Paperless homework: some schools allow learners to turn in papers, assignments or projects in digital format. For many, doing away with paper is an eco-friendly option. Paperless innovation is the new buzzword, and that means doing away with ink, notepads and hardcopy textbooks. The significant advantage of digital is that it eliminates the need to chop down trees to produce paper, which benefits the environment. 


\section{$2^{\text {nd }}$ World Conference On Future Of EDUCATION}

BRUSSELS, BELGIUM

11-13 September 2020

\section{Methodology}

Schwardt (2007) defines research methodology as a theory of how an inquiry should proceed, explaining that it involves an analysis of the assumptions, principles and procedures employed in a particular approach to an inquiry.

\section{Research approach}

The research on which this article is based, was qualitative in nature. Yates, Partridge and Bruce (2012) explain that qualitative research is a phenomenographic approach which explores variations in people's experiences of their world. This approach was deemed best suited for the current undertaking, because the researchers intended to look at a phenomenon holistically, specifically, to gain insight into Accounting teachers' readiness to use mobile phones and various social media platforms as part of their teaching practice. At present, very little is known about the use of mobile phones/other devices and social media platforms as supplementary teaching tools, especially in the context where this research study was conducted.

\section{Design}

As Johnson and Christensen (2008) explain, the research design encompasses the outline, plan or strategy which will be employed to seek an answer (or answers) to the research question(s). For Creswell et al. (2007), the selection of a design must be based on 1) the stated research question; 2) the audience's acceptance of, and familiarity with, the design; and 3) the researchers' training and experience with the various designs available. In this instance, the researchers employed a descriptive case research design, as they were interested in the participants at a case level, and relied on a descriptive framework when analysing the data. One of the most important features of case research is its flexibility, in that it allows for an examination of "a phenomenon in its natural setting", and accommodates the use of an array of data-collection methods (Johansson, 2003). A case research inquiry, such as the one completed here, also involves intense descriptions of a phenomenon or case (Henning, Van Rensburg \& Smit, 2004).

\section{Population}

The study population refers to all the cases on which the researchers intend basing a scientific conclusion, given certain attributes (Welman et al., 2005). For the purposes of this research, all Accounting teachers in the Eastern Cape province of South Africa were taken as the population.

\section{Sample}

Collis and Hussey (2014) explain that a sample is taken to represent the population from which it is drawn. In this research, samples were drawn from four Accounting teachers in the Amatole Education District. Purposive sampling is a selection criterion that guides researchers to choose participants who have the appropriate personal experiences and characteristics which are essential for uncovering the relevant, sought-after information (Merriam, 2009). In this instance, the researchers handpicked participants to be included in the study, based on them possessing the particular characteristics being investigated. Convenient sampling refers to situations where participants are selected because they are easily and conveniently available (Maree, 2015). In this research, the sampled participants were selected because the researchers were able to access them quickly and easily. 


\section{$2^{\text {nd }}$ World Conference On Future Of EDUCATION}

BRUSSELS, BELGIUM

11-13 September 2020

\section{Data-collection instrument}

Best and Khan (2006) define research instruments as tools which are used to collect data for a research study. One research instrument was used in this research endeavour, and that is the semi-structured interview. Such interviews assist in collecting participants' thoughts, beliefs, knowledge, reasoning, motivations and feelings about a particular topic (Johnson \& Christensen, 2008).

\section{Participants}

Four Accounting teachers, from amongst subject teachers across the entire Amatole East Education District, were sampled. These teachers were selected from four different secondary schools; two in rural and two in urban areas. Teachers are expected to use English as medium of instruction (Department of Education [DoE], 2003), hence that was the language used during the semi-structured interviews. The participants were also sampled using the volunteer sampling technique, which refers to a scenario where participants willingly participate in an investigation of this nature (De Vos et al., 2011).

\section{Data analysis}

Neuman (2014) explains data analysis as a process used when transforming research data or gathered information, and making it more meaningful and understandable. The data in this case were analysed by incorporating elements of both content analysis (CA) and data analysis (DA). Content analysis involves analysing the content of data texts, with a view to establishing what relationship content items have with one another. It entails coding and sorting the data content into relevant categories (e.g., messages, themes and patterns) that can be developed into theoretical constructs (Brown \& Rodgers, 2002; Henning et al., 2004). For the current research, the data content comprised words, phrases, sentences, paragraphs and chat exchanges, produced by participants in the form of interview responses. In the context of this study, DA could be interpreted in two ways: 1) it involved working on, and analysing, data as part of discourse (interrelated chunks of extended speech, writing, conversation or communication, rather than only discrete words, phrases, sentences, paragraphs and conversational exchanges) (see Brown \& Rodgers, 2002; Henning et al., 2004); and 2) analysing statements, exchanges or language specific to certain contexts of use. In relation to the present research, DA was done manually.

\section{Ethical considerations}

Permission to conduct the research in the research area was obtained from the relevant authorities, the principal of the school and the school district manager. Accounting teachers were the only participants in the research; their participation was voluntary; and they were made aware of their rights beforehand, including the right to withdraw from the research at any point, without being penalised for it, if they deemed it necessary to do so.

\section{Trustworthiness of the research}

It is important throughout all stages of a research investigation, to ensure the credibility and trustworthiness of the data (Creswell, 2014). For that reason, the researchers triangulated the data to ensure that they understood the insights offered by the participants, and to strengthen the trustworthiness of the findings. 


\title{
$2^{\text {nd }}$ World Conference On Future Of EDUCATION
}

\author{
BRUSSELS, BELGIUM
}

11-13 September 2020

Limitations of the researchLesson observations were not allowed and thus did not form part of the data-collection process. The researchers had hoped to observe Accounting teachers teaching, in order to see how they integrate technology in their lessons.

\section{Presentation of findings}

The first question was "How are mobile phones and social media platforms used to supplement the teaching of Accounting?" To answer this question, the data collected during the interviews gave rise to various sub-themes/categories being identified, as indicated below.

\section{No mobile phones and social media platforms are used in accounting classrooms}

Upon critically examining the participants' responses, it became clear that despite the fact that almost all learners start to use smartphones and social media platforms at an early age, and although such devices possess $21^{\text {st }}$-century features which would be ideal to supplement the teaching of Accounting, in reality none of the study participants made use of such tools. This, despite the fact that most learners spend more time using their phones, than reading books. Participant 1 supported this notion, when asked whether social media platforms can be used as a supplementary teaching tools, stating:

Let me firstly answer you on the cell phone use in the classroom. I am not making use of the cell phone as [a] teaching tool, however, I have heard that in Gauteng they make use of tablets when teaching. But your question has open[ed] my mind [to the fact] that the smartphones learners own, can be used [rather] than wait [ing] for [...] tablets to be provided to our learners, because even their smartphones [...] possess [...] similar features. Coming into the use of social media platforms, even on them I was not aware that they can be used educationally, as a result I don't use them, however, now I fully believe that we are supposed to use them, for example, [by] opening [...] the school's Facebook page and post [ing] notes and question papers on the page, since these learners spend most of their time on these social network[s].

Participants 3 had a similar response:

I am not using social networks and cell phone[s] as a supplementary teaching tool in [any] of my classrooms. But, through your question, I can see that even if I am not using them, [...] the reality is that we have to make use of [...] cell phones, WhatsApp and Face book, because these are the things our learners love the most, [more] than these textbooks and notebooks we are forcing them to read.

The above responses clearly show that the participating Accounting teachers still made use of the traditional teaching method of delivering lessons by following the chalk-and-talk approach, despite the fact that new innovations are popping up in the market, and are being used by learners. This will surely force all educational stakeholders to change the way they do things, if their aim is to meet the demands of a highly technologised workplace and society.

One of the questions asked, was "What challenges do Accounting teachers encounter in utilising mobile phones and social media platforms in their classrooms?" During the interviews, a sub-theme/category emerged, and it is addressed below.

\section{Mobile phone and social media use by learners is prohibited in schools}

When responding to this question, the participants revealed that they encounter numerous challenges when it comes to allowing learners to use their mobile phones freely in class: the 


\title{
$2^{\text {nd }}$ World Conference On Future Of EDUCATION
}

\author{
BRUSSELS, BELGIUM
}

11-13 September 2020

constitutions of their respective schools prohibit learners from bringing mobile phones and similar devices onto the school premises. This prohibition even applies during break times.

As Participant 2 reported:

First of all, [the] carrying of cell phones in the school is not allowed, and this is stated in the constitution of the school. The reason for this is that our school is located in [... ] a township, and there is an assumption that once learners are allowed to carry their cell phones that is going to attract thugs who will come [and] rob [them]. In terms of [...] social media usage, the answer is related to the one I provided you, when answering about cell phone usage.

Participant 4 supported this notion, asserting:

In our school, no learner is allowed to bring his/her own cell phone to the school. Once the learner is found carrying a cell phone it becomes a big case, because we have noticed that they [use] them to do copying when [...] writing test [s] and even classwork - they just google the answers. [...] So, all in all I can say my biggest challenge is the school's constitution. What is the use of adopting the use of social media and cell phone as a teaching tool, while our constitution is against that? To me it is useless.

The above responses clearly show the status quo at schools, which are confronted with many challenges that hinder the successful adoption and implementation of technology.

\section{Discussion of findings}

In this study, the researchers arrived at certain findings after the data had been presented, interpreted and analysed critically, in light of the questions asked. Themes that emerged from the questions asked were discussed with reference to the literature.

\section{No mobile phones and social media platforms are used in accounting classrooms}

The researchers discovered that, even as we live in a century where mobile phones use and social media access are prevalent, and prized for their ability to enable anyone to access almost any information, the sampled Accounting teachers were unaware that they could make use of these platforms for teaching purposes. Worryingly, these devices and platforms are not being used, even though it is clear that modern-day learners are more interested in what is on their phones and social media, than what is printed in textbooks. Because learners are technologically skilled from a very young age, Salameh (2017) proposes using mobile phones and platforms such as Facebook in the classroom, as learners are likely to be able to navigate their way around both. When using mobile phones and social media, teachers can establish classroom discussion forums to create a streamlined experience in which learners interact with them and with one another, at the time and in the place of their choice, to discuss issues related to their subject.

Furthermore, through these platforms, formatted text, links, images and attachments can be sent directly to learners, and instructions can be posted. This is ideal, given Marshall's (2014) earlier observation about how much learners retain when they both hear and see information. With the advent of mobile phones and social media, which combine images, texts and audio all in one, it may be possible to help learners retain more than just 50 per cent of what they see and hear. Nonetheless, as Davis et al. (1989) warn, an information system of high technical performance is basically useless if the users, for whatever reason, fail to adopt and accept the available technology. When Accounting teachers can grab and retain their learners' attention by presenting the subject content in a way that appeals to those learners, they will encourage the latter to think critically about their work, and any interaction (with their peers 


\title{
$2^{\text {nd }}$ World Conference On Future Of EDUCATION
}

\author{
BRUSSELS, BELGIUM
}

11-13 September 2020

and with their teacher) will help to boost their academic achievement. As So (2009) notes, new mobile phone and social media platforms have the ability to organise discussions into relevant units, according to learners' cognitive levels. In that way, their participation can be traced and graded. Failure to use these platforms may have negative implications for content delivery in classrooms where learners' competency levels differ widely.

\section{Mobile phone and social media use by learners is prohibited in schools}

Another finding of the research was that, despite societies becoming increasingly immersed in the Fourth Industrial Revolution in all walks of life, learners are not permitted to carry their mobile phones on them at school, or to use social media to supplement their studies in the classroom. The teaching of Accounting requires teachers and learners to be familiar with search engines so that they can access information to supplement what is contained in textbooks, but the constitutions of the schools in question prohibit the use of these devices and platforms during school hours. Clearly, this does not align with Prensky's (2011) notion that the use of social media and mobile phones allows teaching and learning to continue anywhere and at any time. If these devices were allowed - especially mobile phones - learners could make recordings of discussions and/or lessons, take pictures of important written statements and share these with absent learners, or refer to the material when doing homework. This supports the notion proposed by Salameh (2017), that when teachers encourage learners to use any available technological device to supplement their studies, learners are bound to develop an interest in their work and to expand their knowledge. Furthermore, a teacher's role would be made easier, as s/he would facilitate a lesson and reach many learners at the same time, even from a distance - as would be the case during the Covid19 pandemic. Teachers might pose questions and ask learners to raise their hands in response, when presenting an online virtual class. Some learners might respond verbally, others by writing their responses in a chat box. This aligns with the proposal put forward by Davis et al. (1989) that users need to develop new skills and knowledge of current technologies, by continuously improving their capacity and upgrading their skills. When teachers make use of mobile phones and social media platforms in the classroom, learners could create classroom "blogs" to communicate their knowledge to others, and obtain feedback to further refine their thoughts. This will compel teachers to quickly set deadlines by which learners should contribute to discussions, as a means of managing an open classroom discussion space. However, despite these challenges Accounting teachers need to develop a contingency plan to make use of mobile phones and available social media platforms, to strengthen their delivery of quality education. Furthermore, Accounting teachers need to be workshopped on how they can make use of these platforms, to supplement their teaching.

\section{Conclusion}

This research investigated Accounting teachers' readiness to use mobile phone and social media platforms in their classrooms. To this end, the researchers focused on high schools in the Eastern Cape province of South Africa. They concluded, after a critical review of the findings, that there is an urgent need to ensure that Accounting teachers are well equipped on how mobile phones and social media platforms can be utilised to support teaching and learning. Furthermore, schools' constitutions need to be amended to promote the use of available technologies in the classroom, albeit in a highly structured, managed and efficient way. 


\section{$2^{\text {nd }}$ World Conference On Future Of EDUCATION}

BRUSSELS, BELGIUM

11-13 September 2020

\section{Recommendations}

The digital revolution has changed the manner in which Accounting teachers are expected to deliver their lessons in their respective classrooms. In the $21^{\text {st }}$ century, a great deal of information is available, via technology - more so than any one person could ever hope to acquire. Given the findings reported on here, the researchers recommend that Accounting teachers create discussion board forums and upload teaching materials to the forum, so that they can interact with their colleagues regarding their subject. The researchers further recommend that mobile phones and social media usage be permitted in school, and that learners be allowed to record lessons. Furthermore, the researchers recommend the creation of "teacher blogs" to strengthen the use of mobile phones and social media in Accounting classrooms. Learners are already au fait with most devices, and these technological tools offer teachers a wonderful opportunity to enhance their teaching, while allowing learners to access a variety of platforms to enrich their learning.

\section{References}

[1] Moura, C. and Carvalho, I. (2008). Environmental education in Brazil. Rio de Janeiro: Rodeiro.

[2] Naismith, L. Lonsdale, P. Vavoula, G. and Sharples, M. (2004). Literature review in mobile technologies and learning: Bristol: Futurelab.

[3] Owuse-Acheaw, M. and Larson, A.G. (2015). The effect of social media to the sustainability of Short Message Service (SMS) and phone call. Journal of Computer Science. vol. 11, pp. 687-697.

[4] Olaleke, J. Iroju, O. and Olajide, M. (2015). An assessment of the use of online social network sites for enhancing computing students' academic activities. Journal of Scientific Research and Reports, vol. 5, pp. 489-499.

[5] Cetinkaya, L. (2017). The impact of WhatsApp use on success in education processes. International Review of Research in Open and Distributed Learning, vol.18, 140-152

[6] Van Doorn, G.H. and Eklund, A.A. (2013). Face to Facebook: Social media and the learning and

teaching potential of symmetrical, synchronous communication. Journal of University Teaching and Learning Practice, vol. 10, pp. 1-14.

[7] Lewis, M. (2006). Information Communication Technology in Education. Journal of Applied and Advanced Research. vol. 3.pp.45-59.

[8] Green, H. and Hannon, C. (2007). Using the technology of today, in the classroom today. Massachusetts: MIT.

[9] Ed Technology Tours. (September 2017). Reimagining the role of technology in education: 2017 National

Education Technology Plan Update, US Department of Education. [Online].5(1). Pp.12 available:

http://tech.ed.gov

[10] Davis, F.D. Bagozzi, R. and Warshaw, P.R. (1989). User acceptance of computer technology: A comparison of two theoretical models. Journal of Management Science, vol. 35, pp. 150-165.

[11] Straub, D., Lock, K. and Hill, C. (2012). The use of ICT in teaching and learning of Accounting 


\section{$2^{\text {nd }}$ World Conference On Future Of EDUCATION}

BRUSSELS, BELGIUM

11-13 September 2020

education in Nigeria. Proceedings of 33rd Annual Convention and International Conference of Nigeria Association for Educational Medial and Technology. Oyo State, Nigeria, pp. October 8-202.

[12] Venkatesh, V. Morris, M. Davis, G. and Davis, F. (2003). User acceptance of information technology: Toward a unified view. Journal of Educational Technology Development and Exchange, vol. 27, pp. 160-177.

[13] So, S. (2009). The development of an SMS-based teaching and learning system. Journal of Educational Technology Development and Exchange, vol. 2, pp. 113-124.

[14] Hayati, A. Jalilifar, A. and Mashhadi, A. (2013). Using Short Message Service (SMS) to teach English idioms to EFL students. British Journal of Educational Technology, vol. 44, pp. 66-81.

[15] Cavus, N. and Ibrahim, D. (2009). Mobile-learning: An experiment in using SMS to support learning new English language words. British Journal of Educational Technology, vol. 10, pp. 78-88.

[16] Basoglu, E.B. and Akdemir, O. (2010). A comparison of undergraduate students' English vocabulary learning: Using mobile phones and flash cards. Turkish Online Journal of Educational Technology, vol. 9, 15-29.

[17] Harley, D. Winn, S. Pemberton, S. and Wilcox, P. (2007). Using texting to support students' transition to university. Innovations in Education and Teaching International, vol. 44, pp. 229-240

[18] Salameh, M.T.B. (2017). Challenges to political reform in Jordan. Global Journal of Business Research Management, vol. 12, 56-72.

[19] Hassan, I.S. and Dickson, S. (2014). Facebook as a tool for teaching and learning. Journal Pendidikan Malaysia, vol. 7, pp. 40-53.

[20] Gon, S. and Rawekar, A. (2017). Effectivity of e-learning through WhatsApp as a teaching learning tool. Journal of Medical Sciences, vol. 4, 100-113.

[21] Bere, A.A. (2012). Comparative research of student experiences of ubiquitous learning via mobile devices and learner management systems at a South African university. Proceedings of the 14th Annual Conference on World Wide Web Applications. Durban. South Africa. Pp. 139-149.

[22] Amry, A.B. (2014). The impact of WhatsApp mobile social learning on the achievement and attitudes of female students compared with face-to-face learning in the classroom. European Scientific Journal, vol. 10(22), 120-135.

[23] Marshall, J. (2014). Learning with technology: Evidence that technology can, and does, support learning. Cape Town: Oxford University Press.

[24] Campbell, G. (July2017). There's something in the air: Podcasting in education. [Online]. 21(3). pp. 876-880. Available: http://www.educause.edu/ir/library/pdf/erm0561.pdf [2]

[25] Prensky, M. (August 2011). Digital natives, digital immigrants. [Online]. 11(3). pp. 1533. Available:

https://www.marcprensky.com/writing/Prensky\%20\%20Digital\%20Natives, \%20Digital\%20Immigrants\%20-\%20Part1.pdf

[26] Townend, N. (2015). Podcasting in higher education. Viewfinder, Media Online Focus, British Universities:

Film \& Video Council. 


\section{$2^{\text {nd }}$ World Conference On Future Of EDUCATION}

BRUSSELS, BELGIUM

11-13 September 2020

[27] Sharples, M., Taylor, J. and Vavoula, G. (August 2005). Towards a theory of mobile learning. [Online]

21(3). pp. 150-166. Available:

https://www.researchgate.net/publication/228346088 Towards_a_theory_of_mobile_1 earning.

[28] Kismihok, G. (2007). Empirical research on learners' thoughts about the impact of mobile technology on

learning. International Journal of Mobile and Blended Learning, vol. 3, pp. 30-45.

[29] Schwardt, T.A. (2007). The Sage dictionary of qualitative inquiry. Urbana-Champaign, IL: University of Illinois. Brussels

[30] Yates, C. Partridge, H.L. and Bruce, C. (2012). Exploring information experiences through phenomenography. Library and Information Research, vol.12, pp. 96-110.

[31] Johnson, B. and Christensen, L. (2008). Educational research: Quantitative, qualitative approaches. Michigan: University of Michigan.

[32] Creswell, J.W. Hanson, W.E. Plano Clark, V.L. and Morales, A. (2007). Qualitative research designs: Selection and implementation. The Journal of Counselling Psychologist, vol. 35, pp. 220-235.

[33] Johansson, R. (September 2003).Methodologies in Housing Research [Online] 2(5). pp. 1-14. Available:

http://www.psyking.net/htmlobj-3839/case_study_methodology-_rolf_johansson_ver_2.pdf

[34] Henning, E. Van Rensburg, W. and Smith., B. (2004). Finding your way in qualitative research. Pretoria:

Van Schaik

[35] Welman, J.C. Kruger, F. Mitchell, B. and Huysamen, G.K. (2005). Research methodology. Cape Town: Oxford: Oxford University Press.

[36] Collis, J. and Hussey, R. (2014). Business research: A practical guide for undergraduate and postgraduate students. Basingstoke: Palgrave Macmillan.

[37] Merriam, S.B. (2009). Qualitative research: A guide to design and implementation. San Francisco, CA: Jossey-Bass.

[38] Maree, K. (2015). First steps in educational research. Pretoria: Van Schaik.

[39] Best, W.B. and Khan, J.V. (2006). Research education. London: Allyn and Bacon.

[40] Johnson, B. and Christensen, L. (2008). Educational research: Quantitative, qualitative approaches. Michigan: University of Michigan.

[41] Department of Education. (2003). Revised National Curriculum Statement, grades $R-$ 9(schools): Teacher's guide for the development of learning programmes (languages). Pretoria: Government Printer.

[42] De Vos, A. Strydom, H. Fouché, C. and Delport, C.S.L. (2011). Research at grassroots: For the social sciences and human services professions. Pretoria: Van Schaik.

[43] Neuman, W.L. (2014). Social research methods: Qualitative and quantitative approaches. USA: Allyn and Bacon. 


\section{$2^{\text {nd }}$ World Conference On Future Of EDUCATION} BRUSSELS, BELGIUM

11-13 September 2020

[44] Brown, J.D. and Rodgers, T.S. (2002). Doing second-language research. Oxford: Oxford University Press.

[45] Henning, E. Van Rensburg, W. and Smith. B. 2004. Finding your way in qualitative research. Pretoria: Van Schaik.

[46] Creswell, J.W. (2014). Educational research: Planning, conducting and evaluating quantitative and qualitative research. Upper Saddle River, NJ: Prentice Hall. 